\title{
Effectiveness of Group Counseling Role Playing Techniques to Reduce Student Bullying Behavior
}

\author{
Maya Puspa Rini* \\ Graduate Program \\ Universitas Negeri Yogyakarta \\ Yogyakarta, Indonesia \\ mayapuspa658@gmail.com*
}

\author{
Ayu Iswara \\ Graduate Program \\ State Islamic University Raden Intan \\ Lampung, Indonesia \\ ayuiswara@yahoo.com
}

\begin{abstract}
The purpose of this study was to determine the bullying behavior of students and to determine the effectiveness of the use of role playing in reducing the bullying behavior of State High School 1 Bandar Lampung students. The method used in this study is a quasi-experimental study with Nonequivalent Control Group Design. The sample in this study amounted to 34 students of Bandar Lampung State High School 1 who carried out bullying behavior in the high category. Data collection techniques in this study used a scale of bullying behavior, interviews, observation and documentation as supporting techniques. The results of the calculation of the average score of the bullying behavior of the experimental group at the time of the pre-test were 82.58 and the post-test acquisition after participating in the role-playing group counseling service decreased to 71.41. Whereas in the control group at the time of the pre-test was 74.94 and at the time of the post-test it had decreased to 68.94. So, who is rejected and $\mathrm{Ha}$ is accepted, which says role playing can reduce student bullying behavior at Bandar Lampung 1 State High School.
\end{abstract}

Keywords-group counseling, role playing, bullying behavior

\section{INTRODUCTION}

Children are the nation's assets that will become the next generation of this nation. How is the condition of the child today affecting the condition of the nation in the future? It is important for all parties, both families, communities, and governments to participate in protecting and guaranteeing all forms and children's rights so that they can grow and develop properly, and free from all forms of discrimination and violence. Children's rights are not enough to be free from all forms of discrimination and violence, but education is also a right for children. This is stated in Law No. 23 of 2002 concerning child protection, article 9 which reads "every child has the right to receive education and teaching in the context of personal development and the level of intelligence according to their interests and talents" [1]. Through education, children grow into quality adults and have skills and knowledge that can develop their potential. The achievement of the law certainly does not go well just like that. Many of the problems that arise one of them is about the problem of bullying informal education institutions (schools) which is rife lately. Bullying is a global problem and can be defined as a series of aggressive physical, verbal, and relational behaviors that occur repeatedly against a helpless person over a long period of time [2].

Bullying that occurs in some forms of bullying is divided into three types, namely: a. Physical Bullying Physical oppression is the most visible and most identifiable type of bullying among other forms of bullying, but the incidence of physical bullying accounts for less than one- third of the reported incidents of bullying reported by students. Types of physical oppression include beating, strangling, elbowing, punching, kicking, biting, crunching, clawing, and spitting on an oppressed child to a painful position, and damaging and destroying clothing and items belonging to an oppressed child. The stronger and more mature the bully is, the more dangerous this type of attack is, even if it is not intended to seriously injure. b. Verbal Bullying Verbal violence is the most commonly used form of oppression, both by girls and boys. Verbal violence is easy to do and can be whispered in the presence of adults and peers, without being detected. Verbal oppression can be shouted at the playground mixed with the ringers who are heard by supervisors, ignored because it is only seen as a stupid and unsympathetic dialogue between peers. Verbal oppression can be in the form of nicknames, reproaches, slander, cruel criticism, insults, and nuanced statements of sexual solicitation or sexual harassment. In addition, verbal oppression can take the form of appropriation of pocket money or goods, abusive telephone calls, intimidating e-mails, anonymous letters containing threats of violence, improper accusations, vicious gossip, and gossip. c. Relational Bullying This type is the most difficult to detect from the outside. Relational oppression is the weakening of the victim's self-esteem in a systematic way through neglect, exclusion, exclusion, or avoidance. Avoidance, an act of elimination, is the strongest means of oppression. The gossiped child may not hear the gossip, but will still experience the effect. Relational oppression can be used to alienate or reject a friend or intentionally destroys friendships. These behaviors can include hidden attitudes such as aggressive gaze, eye glances, sighs, shaking shoulders, sneering, mocking laughter, and rough body language. Bullying is an act and behavior that cannot be tolerated because if left unchecked, bullying behavior will negatively impact both the perpetrator and the victim [3]. The teacher is very confident in the scope of the school to prevent bullying behavior and 
to identify its impact on the bullying behavior of students at school [4].

Bullying is when one or more students tease, threaten, spread rumors, about, encourage or hurt another student repeatedly. Not intimidation when two students with the same strength or strength argue or fight or tease each other in a friendly way [5]. The role-playing technique is a method that is often used in teaching values and solving problems faced in social relations by given certain roles and performing certain roles, and discussing them in class. Research in China examines the correlation between bullying and psychosocial settings. The results show that $6.3 \%$ of children reported having been intimidated in the last 3 months, $2.5 \%$ of children claimed to intimidate other students, and $2.2 \%$ said they were intimidated and intimidated by others in the same period. More boys than girls report intimidation and become victims of bullying. U.S. Department of Education found that $23 \%$ of public school students aged between 12 and 18 years were reported to be being bullied [6]. Reports from the Centers for Disease Control and Prevention also indicate, from a national representative sample of students aged $12-18$, that $28 \%$ of young people are reported to be intimidated in schools (Centers for Disease Control and Prevention, 2012) [7].

Based on the results of the pre-study with the Guidance and Counseling teacher, it was found that there were a number of bullying behaviors which tended to be carried out by the 11th grade MIPA of State Senior High School 1 Bandar Lampung compared to other classes, there were several forms of bullying behavior that occurred such as verbal bullying, relational bullying, physical bullying that occurred in 60 XI MIPA students of State Senior High School 1 Bandar Lampung. Based on the table it can be seen that out of 136 students there were 60 cases of students who had bullying behavior namely: there were 25 students $(41.70 \%)$ who exhibited verbal bullying behavior, 20 students $(33.40 \%)$ who committed psychological bullying, there were 15 students (25\%) who did physical bullying. Thus it can be concluded that the problem of bullying behavior in class XI MIPA students of State Senior High School 1 Bandar Lampung still often occurs. As happened in class XI MIPA 3 where this class compared to other classes is more dominant some students do bully behavior. This is reinforced by the results of interviews with students of class XI MIPA of State Senior High School 1 Bandar Lampung on November 9, 2016, which can be concluded as follows: "I often spread gossip, make nicknames to mock, and beat my friends, but most of it happens because various things because they are accustomed to bullying behavior and environmental influences. "Based on the results of the interview, according to the statement made by Mrs. Wartini, explaining that:" I think children of class XI MIPA 3 still have students who practice bullying towards their friends. his friends like insulting, berating, intimidating, isolating. " In this study, the researchers used group counseling to assist in problem- solving (if necessary, by applying specific methods), evaluation activities and follow-up. One of the most important things is the dynamics of social interaction that can develop intensively in a group atmosphere and combined using role-playing techniques [8]. Role-playing technique for students is an action that is used to deal with students with bullying behavior that has become a student's habit so that it harms others both friends and the school environment. By exchanging roles between victims becoming bullying actors and conversely perpetrators becoming victims. This method is very possible to make the perpetrators aware that what he did was a mistake. By playing the victim as the perpetrator, the victim is expected to be made aware that what the perpetrator has done is a mistake, so the victim will not become a perpetrator in the future as a form of revenge. Through this method can train victims to be assertive and victims assertively defend their rights so as not to do it to others. For the perpetrators, they can feel what the victim feels so they are aware of their mistakes. Then the purpose of this research is to reduce bullying behavior in Bandar Lampung 1 State Senior High School through role-playing methods. Evaluation of the effectiveness of school programs related to bullying behavior in the school environment is very necessary to reduce bullying behavior in schools [9].

\section{METHODS}

The method used in this research is quasi-experimental. in the design of the quasi-experimental method, there is a control group and the experimental group the experimental design used in this study is the Non-equivalent Control Group Design. In the two groups, the pre-test and post-test were both conducted. However, only the experimental group was given treatment. This experimental design was used because, in this study, there were experimental groups that would be given treatment and a control group as a comparison, in the two groups the measurements would be carried out twice, namely before and after treatment. First the measurement (pre-test), then the experimental group was treated using classroom management with a social cognitive approach, but the control group was not given full treatment as in the experimental group, then re-measured (post-test) to see there or whether or not the effect of the treatment that has been given to the subjects studied. In this study, the population was students of class XI MIPA in State Senior High School 1 Bandar Lampung, to find a comparison of bullying behavior, the number of samples of class XI MIPA was divided into 2 groups as the experimental class and the control class. In this study the population numbered 34 (thirty-four) XI MIPA students of State Senior High School 1 Bandar Lampung. Data collection techniques used in this study used a scale of bullying behavior, interviews, observation, and documentation. Researchers used the scale used, namely the scale of bullying behavior. Likert scale is used to measure the attitudes, opinions, and perceptions of a person or group of people about social phenomena [10].

\section{RESULT AND DISCUSSION}

Result

Based on the results of the spread of bullying behavior instruments towards 136 students of class XI MIPA of SMA Negeri 1 Bandar Lampung. Subjects in this study were students of class XI in the State High School 1 Bandar 
Lampung, totaling 34 students. Pre-action activities carried out by researchers through observation and pre-test of class XI students in State Senior High School 1 Bandar Lampung. the percentage of bullying behavior profile of students which are further categorized into three criteria as listed in Table 1 as follows:

Table 1. General Description of Bullying Behavior of Students

\begin{tabular}{|c|c|c|c|c|}
\hline No & Criteria & Rating & $\sum$ & Persentase \\
\hline 1 & High & $\geq 75-100$ & 17 & $40.47 \%$ \\
\hline 2 & Is & $\geq 47-74$ & 10 & $33.80 \%$ \\
\hline 3 & Low & $\geq 20-46$ & 9 & $25.73 \%$ \\
\hline \multicolumn{3}{|c|}{ Amount } & 34 & $100 \%$ \\
\hline
\end{tabular}

Pretest-posttest score data of student bullying level in the experimental group and the control group, as follows:

Table 2. Paired Samples

\begin{tabular}{|c|l|c|c|c|c|}
\hline \multicolumn{2}{|c|}{} & mean & $\mathrm{N}$ & $\begin{array}{c}\text { Std. } \\
\text { deviation }\end{array}$ & $\begin{array}{c}\text { Std. Error } \\
\text { Mean }\end{array}$ \\
\hline Pair 1 & Pretest & 82.59 & 17 & 6.671 & 1.618 \\
\cline { 2 - 6 } & Posttest & 71.41 & 17 & 1.583 & .384 \\
\hline
\end{tabular}

Based on data calculations with paired samples statistics that there are differences in the average value before and after the role-playing technique is given. Before the roleplaying technique is given to students, the average value is 82.59 and after the role- playing technique is given, the average value is 71.41 . Then it can be concluded that effective role-playing techniques are given to reduce the bullying behavior of the students of Class XI MIPA in the State High School 1 Bandar Lampung.

Tabel 3. Paired Samples Test

\begin{tabular}{|c|l|c|c|c|c|}
\hline \multicolumn{2}{|c|}{} & mean & $\begin{array}{c}\text { Std. } \\
\text { deviation }\end{array}$ & $\begin{array}{c}\text { Std. } \\
\text { Error } \\
\text { Mean }\end{array}$ & t \\
\hline $\begin{array}{c}\text { Pair } \\
1\end{array}$ & Pretest & 11.176 & 6.588 & 1.598 & 6.995 \\
\cline { 2 - 4 } & Posttest & & & & \\
\hline
\end{tabular}

Based on the paired sample test it is known that the sig (2-tailed) value is $0.000 \leq 0.05$. The t-value is smaller than $\mathrm{t}$ count $(2.11991 \leq 6,995)$, by conducting t-test, looking for the $\mathrm{t}$-count to be compared with t-table, t-test is used to determine the quality of the regression significance between each independent variable (X) there is an influence or not to the dependent variable $(\mathrm{Y})$. this shows that there is a significant difference in score between t-table and t-test. Then it can be concluded that group counseling with role playing techniques is effective in reducing bullying behavior of students of class XI MIPA 1 State Senior High School Bandar Lampung.

\section{Discussion}

The results showed that role-playing techniques can reduce bullying behavior in students at Bandar Lampung 1 State High School. This is indicated by the categorization in the pre-cycle and cycle I also decreased bullying behavior mostly into low categories. However, after treatment using the role-playing method, it is known that the perpetrators' awareness reduces bullying behavior. There is also an increase in empathy for the offender can make the offender realize that what he did was a mistake. Victims who are assertive will reduce bullying behavior in the future. Victims also should not just be silent about bullying behavior, this is to make the perpetrators aware that what he did was wrong. A silent witness who is silent will also bring up potential, which will make him the next victim. Witnesses who are assertive and willing to act or participate in the fight against bullying can reduce the number of victims and perpetrators of bullying. The results of this study also showed that students liked the application of role-playing methods in the Guidance and Counseling Services.

\section{CONCLUSION}

Based on the results of the study "Effectiveness of Group Counseling Services with Role Playing Techniques to Reduce Bullying Behavior of Students in State High Schools 1 Bandar Lampung", it can be concluded the results of the study show that bullying behavior in class XI students of State Senior High School 1 Bandar Lampung that there was a decrease in bullying behavior by 11.17 points in the experimental group from 82.58 to 71.41 , while in the control group decreased bullying behavior by 6 points from 74.94 to 68.94. The results of the $t$ independent sample $t$-test show that the sig (2-tailed) value is smaller than the critical value of $0.005(0.00000 .005)$, this shows that Ho is rejected and $\mathrm{Ha}$ is accepted, and the results of the paired sample test are known to be sig (2-tailed) amounting to $0.20 \geq 0.05$. The value of $t$-table is smaller than $t$-count $(2,119 \leq 2,582)$. This shows that there is a significant difference in scores between t-table and t-count. Then it can be concluded that group counseling with role-playing techniques is effective in reducing the bullying behavior of grade XI students of Mathematics and Natural Sciences State Senior High School 1 Bandar Lampung.

\section{ACKNOWLEDGMENT}

The author thanks parents who have provided material and moral support. The author also thanks friends who have supported and provided encouragement and motivation in journal making.

\section{REFERENCES}

[1] Undang- Undang RI No. 23 Tahun 2002 Tentang Perlindungan Anak. Jakarta: Sinar Grafika.

[2] S. Wachs, L. Bilz, S. Niproschke, “A Multilevel Analysis of Teachers' Success in Handling Bullying from the Students' Perspective", Journal of Early Adolescence, vol 39, pp. 1-27, Juni 2018.

[3] E. Young, D. Song "Interactive Computing Technology in AntiBullying Education: The Effects of Conversation-Bot's Role on K-12 Students' Attitude Change Toward Bullying Problems", Journal of Educational Computing, vol 22, pp. 1-20, April 2019.

[4] P. Jac, "The effects of general interpersonal and bullying-specific teacher behaviors on pupils' bullying behaviors at school", School psychology international, vol 36, pp. 467-481. Juli 2015.

[5] N. Geres, P. Orpinas, "Bullying and Attitudes Toward Masculinity in Croatian Schools: Behavioral and Emotional Characteristics of Students Who Bully Others", Journal of Interpersonal Violence, vol 32, pp. 1-18. Mei 2018 .

[6] H. Zhang, H. Zhou, "Bullying Behaviors and Psychosocial Adjustment Among School-Aged Children in China”, Journal of Interpersonal Violence, vol 34, pp. 1-13. Juli 2018. 
[7] D. Upton, J. Sung, “. A Systematic Review of Research Strategies Used in Qualitative Studies on School Bullying and Victimization", Trauma, Violence, \& Abuse, vol 18, pp. 1-14. Juni 2015.

[8] Prayitno \& Amti, Dasar-Dasar Bimbingan dan Konseling. Jakarta: Rineka Cipta, 2012.
[9] M. Wojcik, A. Helka, "Meeting the Needs of Young Adolescents: ABBL Anti-Bullying Program During Middle School Transition", journals.sagepub.com, vol 122, pp. 1-25. April 2018.

[10] Sugiyono. 2013. Metode Penelitian Kuantitatif Kualitatif dan $R \& D$. Bandung: Alfabeta. 